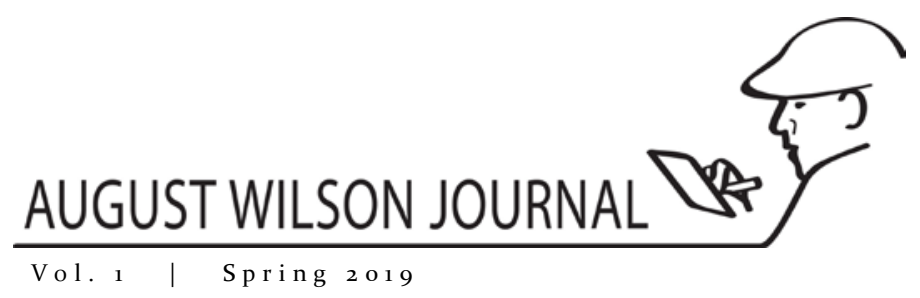

\title{
A Front Row Seat: Sala Udin Remembers August Wilson
}

\author{
By Christopher Bell \\ Associate Professor of English, University of North Georgia \\ The language of the characters in August's plays talked exactly the \\ way we did on the street. And we had never seen that before. \\ - Sala Udin
}

\begin{abstract}
Lifelong friend of August Wilson, Sala Udin, shares his memories of knowing the playwright from their childhood in the Hill District until the dramatist's death in 2005. Written as a narrative, Udin's account of his friendship with August Wilson offers a unique glimpse into Wilson's development as a writer and a poignant look into the playwright's affection for his hometown of Pittsburgh,

Pennsylvania.
\end{abstract}

Keywords

August Wilson, Sala Udin, Hill District, Chris Bell, Pittsburgh Playwrights Theatre, St. Richard's School, Rob Penny, Civil Rights Movement, Black Horizons Theater, Pan Fried Fish

Any understanding of the American playwright August Wilson begins with an understanding of the Hill District. Here, in the historically black neighborhood that borders downtown Pittsburgh, Pennsylvania, Wilson was born Frederick August Kittel in 1945 at

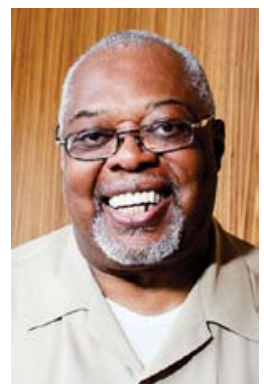

Sala Udin

1727 Bedford Avenue. Known as Freddy, the young Wilson was raised in a two-bedroom apartment that eventually housed him, his mother, and six siblings. Wilson experienced the radical changes that occurred in the Hill during the next thirty years, as the once solidly working-class neighborhood decayed slowly, the victim of broken promises from local government. In Wilson's much celebrated American Century Cycle, ten plays that chronicle the black American experience of the twentieth century, the

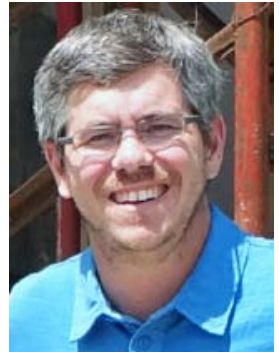

Chris Bell dramatist depicts the lives of Hill District residents

as they struggle to live in a world that appears to have willfully turned its back on their existence. This is especially true of the plays set in the decades after the 1950s. The fidelity with which Wilson writes about the Hill District is complemented with a fiery political subtext centered on principles the playwright embraced before he achieved success as a mainstream playwright, principles rooted in the ideology of the Black Power Movement of the late 196os. Although Wilson's childhood story and its link to the Hill District is fairly well told, one individual who offers unique perspective is Sala Udin, whose birth name is 
\begin{tabular}{l|ll} 
Vol.1 & Spring 2019
\end{tabular}

Sam Howze. He was born in the Hill District in 1943. Udin figures as a kind of Zelig in the life of August Wilson. The two went to elementary school together. Later, Udin and Wilson stood shoulder to shoulder as participants in the Black Liberation Movement of the 196os. In 1982, as Wilson slowly worked his way to mainstream success, the playwright tabbed his friend to play the lead in his first major regional production, Jitney. When Wilson was struck with terminal cancer, he enlisted Udin to play a role in ensuring his burial wishes. Ultimately, Udin's recollections about August Wilson are tied inextricably to memories of the neighborhood the dramatist immortalized, memories that are, to quote Joe Turner's Come and Gone, "both a wail and a whelp of joy."

\section{The Hill District: 1940s and 1950s}

Sam Howze first met Freddy Kittel when the two attended Holy Trinity Catholic Elementary School, located on Fullerton Street in the Lower Hill District. Kittel lived in the Middle Hill, walking a few blocks to and from. Both the school and the street are gone now, but Udin fondly remembers the bustling area filled with bars, jazz joints, restaurants, movie houses, and even brothels. Udin insists the environment was safe for children: "There was no static between police and residents of the Lower Hill. And everybody worked." At this time, the Hill was a largely multiethnic neighborhood, a mostly conflict-free mixing of Syrians, Jews, Italians, ethnic Germans such as Wilson's father, and African Americans, amongst other ethnicities. Although Fullerton Street was the Hill District's pulse, Udin notes that Wilson experienced the electricity despite living on Bedford Avenue several blocks away, if for no other reason than he walked the streets almost daily. But at Holy Trinity, Freddy Kittel stood apart from his classmates. Udin remembers he "was kind of different from most kids. He didn't do a lot of running around and wrestling and physical stuff like that. He tended to stand just outside the circle of activity and observe everybody and what they were doing but did not participate as much."

The vibrancy of Fullerton Street was soon obliterated. City planners decided the Lower Hill needed a facelift, believing the area depressed. Udin admits his memories of Fullerton Street are rather halcyon. The area needed improvement, especially many of the buildings. Some were over a hundred years old and in a state of disrepair. But Udin adamantly denies the area was blighted. The city's opinion differed, and the planners brought wrecking balls. The Lower Hill was demolished, several hundred businesses were destroyed, and several thousand residents displaced. Most actually moved out of the Hill, relocating to the Homewood neighborhood. The Howze family, coincidentally, found itself coincidentally at the Bedford Dwellings housing projects on Bedford Avenue, several blocks from where the Kittels lived behind Siger's Grocery, although the young Sam Howze did not know this at the time. The two found themselves at St. Richard's School. Udin recollects, again, that Freddy remained mostly quiet, sometimes with the suggestion of a grin on his face as he observed his classmates.

At this point in their lives, outside forces were shaping both young men in ways neither could have known. Despite a promise to rebuild the Lower Hill, city planners reneged. Virtually no affordable housing replaced that which had been obliterated, and Fullerton Street was wiped clean from city maps. Instead, the Civic Arena, a multipurpose entertainment complex, became the enduring legacy of the Lower Hill's destruction, along with several parking lots built to accommodate visitors, most of whom came from areas of the city other than the Hill District. By the end of the 1950s, Sam Howze and Freddy Kittel had left the Hill. They would find themselves side by side a decade later with a shared purpose of raising the conscience of their community and revitalizing their neighborhood. 


\section{The Hill District: Late 196os and 1970s}

By the late 1960s, the Hill District had dramatically changed. Urban renewal planners had leveled the Lower Hill, and the Middle Hill was dramatically overpopulated, leading to worse housing conditions. Tension between the police and the local black populace was palpable. Employment, especially for young black males, was scarce. And while Hill District residents managed to stop a second wave of urban renewal that targeted the Middle Hill, the damage city planners had already wrought seemed irreparable. Then, in the spring of 1968, riots occurred in response to the assassination of Dr. Martin Luther King, Jr. The neighborhood burned for days. In time, the riots came to be seen as the final blow to the neighborhood's near annihilation.

August Wilson and Sala Udin, no longer Freddy Kittel and Sam Howze, stepped into this cauldron with a shared focus on how to solve the Hill District's problems. They had become, according to Udin, "soldiers in the Black Liberation Movement." By the late 196os, Udin was something of a veteran of the Civil Rights Movement, having been present at the National Mall when King delivered his "I Have a Dream" speech. But by the end of the decade he had become radicalized, aligning himself with the Black Power Movement. Wilson had undergone similar changes. Approximately two years after leaving the Hill, Wilson had dropped out of high school and educated himself by reading voraciously at the Oakland branch of the Carnegie Library. Most importantly, he discovered the Negro section of the stacks and began imagining his own contributions on the shelves. Both Wilson and Udin adopted new identities as well. A local Iman gave Sam Howze the name Sala Udin, who historically "was a north African emperor [who] was a scholar and very inquisitive student, and the people of his land honored him by putting his name in the dictionary to define one who seeks knowledge." Meanwhile, Freddy Kittel formally embraced his mother's heritage by taking her surname, rechristening himself August Wilson. Udin comments on the effect of adopting a new identity during this turbulent time:

It was keeping step with a trend among progressive African Americans in my age group who were adopting African-centered cultural norms across a broad array of practices. Name changing was one. Religion changing was another. Hair style changing was another. Clothing changing was another. We were participants in a Black Liberation Movement that was centered in African culture, and so it would be expected, especially among leaders, that European names would be dropped and replaced with either African names, or, if there was an Islamic bent to the Africanization, then a kind of African-Islamic name would be selected.

Although Wilson did not take an African-centered name or start wearing such clothing, Udin still says the change from Freddy Kittel to August Wilson was transformational: "Any change from the slave tradition was fine, and so August acknowledging his mother's lineage made sense."

The primary identity Wilson adopted was that of writer. In the late 1960s he saw himself as a poet, although a reluctant one. He remained the insular child Udin remembered from some fifteen years earlier when the two were schoolmates:

August was a shy person. He was vocal and verbal whenever he decided to speak, but he was ordinarily shy and reserved and quiet, the same way we were raised, the same way I had known him from the old days. He read his poetry only reluctantly. He had to be asked several times to read his stuff, and then he would read it. He was serious, deeply intellectual, but always with an eye out for the humorous. He liked laughing, especially at irony or satire.

Little remains known of the poetry Wilson wrote in the late 1960s. Udin admits too much time has passed for him to recollect its content. Although the future playwright published a couple of poems at this time, they remain little more than curiosities of a young writer trying to find his voice. But Wilson was determined. Although Udin was not active, he 
recollects that Wilson was part of a group that christened themselves Poets in the Centre Avenue Tradition, which met to share their work and support each other at the Halfway Art Gallery, another building long since demolished by the city of Pittsburgh.

For Wilson and Udin, the shared interest in knowledge, art, and black activism crystallized in their work for the Black Horizons Theater. Wilson co-founded the company with Rob Penny and University of Pittsburgh student activists and professionals. Penny, a Hill District resident, poet, and professor at the university, was a mentor of sorts to Wilson. Although Wilson said in later interviews that he was the company's director, Udin, who was involved from the company's inception as its lead actor, says Penny directed and Wilson was more of an assistant director or dramaturg: "You can't have two directors," he notes with a chuckle. Whatever their individual roles, Udin notes with fierce pride, all were "soldiers in the Black Liberation Movement." Black Horizons was largely influenced by Amiri Baraka "and the black theater movement that he created in Harlem and Newark, New Jersey. We went there several times to see the Spirit House Movers and to be influenced by Baraka. So when we began to put together Black Horizons Theater, it was with the Spirit House Movers as a model of what we were trying to recreate here in Pittsburgh." Looking back on the experience, Udin says, "It was groundbreaking."

But the work was also exhausting and expensive. Like many community theaters, Black Horizons was self-funded, and they rehearsed at night, following a regular work day. Udin himself, for instance, helped run a drug rehabilitation center as his day job. Therefore, in the early 1970s, when a woman named Vernell Lillie stepped in and essentially folded Black Horizons into what became the Kuntu Repertory Theatre, Udin was relieved. Kuntu became ensconced within the University of Pittsburgh, effectively solving its financial problems. And while Rob Penny (who already had tenure at the university) and Wilson continued working with Lillie, Udin "drifted away into more political work. My plate was so full that I said, 'If I can let anything go, I need to let some things go. I've done my due in black theater. I'm really interested in getting involved with the university theater. I don't have any theatrical professional ambitions. So I'm out of here.' I went on to continue doing the political work that I was doing."

Importantly, during his time with Wilson in Black Horizons, Udin saw important changes in Wilson. He began to grow out of Rob Penny's shadow. Although "August continued his assistant director role when Kuntu began, he was beginning to develop his own approach to theater direction." He also began writing plays but remained reticent about his work. "He physically carried his stuff with him, and you could never convince him to show his plays. He would read his poetry from time to time." Then, "He allowed one or two of his plays that he had secretly written to be removed from the safe." But just as this new work began to emerge, Wilson left Pittsburgh for Minnesota. The leaving created a void within Wilson that he would fill by putting black Pittsburgh on the stage some five years later. Udin found himself reluctantly front and center.

\section{The Hill District: 1982}

At the dawn of the 1980s, the Hill District of Sala Udin's and August Wilson's childhood was a memory. The problems that plagued the neighborhood throughout the 1960 and 1970s had decimated the area. Employment was at an all time low at the dawn of the Reagan Era. Tensions with the local police continued to increase. Open air drug markets were common. Conditions were so poor that there was not even a full service grocery store in the Hill, the beginning of a thirty year period in which residents lived in a "Food Desert," a condition in which healthy food choices are nearly impossible to find, while the expensive, unhealthy kind of sugar-laden food found at corner markets is the primary option. And while Udin says that the kind of rampant violence depicted in popular media centered on black neighborhoods in the 1980 os was not the reality, many young black men met their fate 
at the hands of their peers, a reality far removed from Udin's experience growing up in the area.

By 1982, Wilson had been gone nearly for nearly five years, although he came back to Pittsburgh frequently. During one of these visits, Wilson tracked Udin down and learned he himself was planning on leaving for California. Wilson protested and countered with an interesting proposal: he had a new play he was preparing for production, and he wanted Udin to play the central character. Udin balked. He hadn't been on the stage in nearly ten years. Wilson was insistent. Udin recounts their conversation:

I said, “August, I haven't been on stage in a long time. I haven't been on stage since Black Horizons Theater."

"This is you in this play," Wilson replied.

"I'm leaving town. I'm on my way to California."

"Yeah, but I developed this character with you in mind."

"Well, maybe we can work together to find somebody to fill that character."

"I developed this character with you in mind. Let's take one step at a time. Read the script."

Wilson's command did the trick. Udin found the play so compelling that he knew immediately he could not turn down the opportunity to perform in it.

The play was titled Jitney. Set in the 1970s, the drama has two central conflicts. The first reflects that which engaged Wilson and Udin in local activism some ten years before Wilson wrote the play. The central character, Becker, the one whom Wilson wanted Udin to play, operates a marginally illegal cab service in the Hill District. Such a business was a necessity in the Hill District, as licensed cab companies would not serve the area. Early in the play, Becker announces that the City of Pittsburgh plans to demolish the building he uses to run his operation, and the drivers must decide if they want to find a new base of operations or stand up to the city. The characters ultimately choose the latter, a defiance rooted in their frustration at the city's decades old practice of leveling what they perceive as viable dwellings, be they homes or businesses. Interestingly, however, Udin does not mention this aspect of the play when he discusses how he came to agree to perform. He points to the second conflict: "I read the script and became captivated by it because of the conflicted relationship between Becker and his son. That caught me." This conflict centers on Becker's son Booster's release from prison after serving twenty years for murdering his then-nineteen year old white girlfriend, who, when caught by her father in a consensual sexual relationship with Booster, claims rape. Booster, believing he will go to prison for a crime he did not commit, kills the young woman, claiming if he is going to be locked up, it must be for an actual offense. Twenty years later, even after his release, he refuses to apologize for his actions. His father, believing his academically gifted son threw away his future, refuses to reconcile when his boy tries to do so. Ultimately, Becker dies with the tension between the two unresolved.

Certainly, Udin would have been motivated by the subtle political component of the play. It dramatizes the kind of issue he had been engaged in his entire life and is reminiscent of the kind of theater Black Horizons staged a decade before Wilson wrote Jitney. But Udin's more intense attraction to the father-son conflict hints at what audiences would come to admire most about Wilson's dramas once they became a national phenomenon: the heartbreaking humanity he imbues in his characters, the laughter that accompanies the tears, the lack of apology for even the most damaging choices they make, and, most important, a fidelity for the Hill District and its residents that jumps off the page. This latter characteristic of Wilson's drama did not surprise Udin because he had witnessed it. Udin says that during Wilson's visits to Pittsburgh after his move to Minnesota, the two, along with Rob Penny, met often at a restaurant they dubbed "Pan Fried Fish," as the owner, Cliff, and his brother "were too ornery to give the place a name. And Cliff didn't like people. But he needed to sell fish sandwiches to make a living, so he sold fish sandwiches. But he didn't 
feel the need to give the place a name. He just put a sign in the window that said 'Pan Fried Fish.' A sign written on a piece of cardboard." The kind of affection Udin describes for the curmudgeonly Cliff is what he recognized in the characters when he first read Jitney. He elaborates on the get togethers at Pan Fried Fish: "Whenever Rob Penny and I arrived to meet at Pan Fried Fish, August would have already been there. But he wasn't at Pan Fried Fish. He was next door at the jitney station, sitting on the floor, with his pad and pencil in his hand, laughing." The burgeoning playwright was recording the conversations of the men in the station, mostly community elders:

They talked about their achievements in the Negro League, about statistics, you know how those barbershop arguments go, about their exploits with women. All lies. But August loved it. He loved sitting there listening to them talk. And so when he told me that the name of the play was Jitney and it took place in a jitney station, it made absolute sense, because that jitney station is usually where we could find August whenever we agreed to meet at Pan Fried Fish.

For Udin, Jitney was a near documentary of the neighborhood where he had lived nearly his whole life. And this was why he agreed to return to the stage. "And I called my friend who I was about to leave with for California and said, 'Man, we gotta delay our departure date. We gotta do this play.' And I told August, 'I will do it."'

The local reaction to Jitney mirrored the experience Udin had when he first read it. Udin elaborates on the experience:

When the play opened, the audience was only half full. But the word then went around that an August Wilson play was opening. And it had the names of Hill District characters, and streets, and locations. And it was funny as hell. And it was gripping dramatically. And the language of the characters was street language. It wasn't cleaned up like we were accustomed to seeing on television. The language of the characters in August's plays talked exactly the way we did on the street. And we had never seen that before. And we loved it. And by the third week the house was full. The shows were sold out. And by the time we had gotten to the fourth week, which is what our original commitment was, it took that long for the word to get around, and people demanded that the show be extended. And I said "August, I'm on my way to California, man. I can't stay." He said, "two more weeks. Two more weeks." So I gave him two more weeks. And the show finally closed, and I packed up and left Pittsburgh for California in 1982.

Although Udin was only gone from the Hill District for a decade, both his and Wilson's lives continued to change in more dramatic ways than perhaps either could have predicted when their friendship began in earnest in the late 196os, even as Wilson ceased to belong to the Hill District and began to belong more to the world.

\section{The Hill District: Late 1990s and Early 2000 s}

By the late 1990s, the steady decline of the Hill District appeared to have peaked. Many began to suggest the Hill was showing signs of significant improvement. When asked about this perspective, Udin demurs. He returned to the Hill permanently in the 199os, and his subsequent election to city council sparked some positive change. He worked to close some of the more notorious after-hours spots in the neighborhood, spearheaded improvements between the police and Hill District residents (centered mostly on making officers more accountable for aggressive behavior), and worked in support of various other progressive causes.

Udin watched from afar as one of the Hill District's former residents, August Wilson, became the most acclaimed American playwright of the late twentieth century. Even as Jitney became Wilson's first regional success in 1982, his national reputation was beginning to brew. At the same time Udin inaugurated the role of Becker in Jitney, Wilson's 
play Ma Rainey's Black Bottom, which would prove to be his breakthrough success, had already been accepted at the prestigious Eugene O'Neill Playwright's Conference. He had also written an early draft of Fences, which would win Wilson's only Tony Award and the first of two Pulitzer Prizes. Udin was privileged to read both nascent versions of Ma Rainey's Black Bottom and Fences, but after Jitney, the two became, in Udin words, "distant." Wilson's profile skyrocketed, and he began what essentially became a life on the road. His plays became part of a workshop cycle wherein each was honed in regional productions throughout the country before finally premiering on Broadway. Subsequently, Wilson returned less often to the Hill District. Udin's connection with his friend continued through the playwright's work. Ever the reluctant performer, Udin still found time to perform in Fences, Two Trains Running, The Piano Lesson, and Ma Rainey's Black Bottom.

Udin distinctly remembers one of Wilson's visits to Pittsburgh in 1999. The Pittsburgh Public Library system honored Wilson with a high school diploma in 1999, the first of its kind. At the ceremony, Udin says, Wilson "told the mayor, 'I think Sala Udin should be the mayor." Later, "We hung out in Shadyside. We got drunk. And I have no idea how we got home." This turned out to be the last time the two friends saw each other.

August Wilson died on October 2, 2005, less than a year after being diagnosed with liver cancer. The playwright was specific about his funeral arrangements, and he enlisted Udin to help ensure his wishes be granted. Before Wilson died, Udin received a call from Wilson's wife, Constanza Romero. He learned that before Wilson died, "he left explicit instructions about who was to do what, what his funeral was to be like, and where he was to be buried." Udin was to serve as the emcee of the funeral and arrange for it to take place at St. Paul's Cathedral, where many prominent Pittsburgh Catholics have been laid to rest over the years. However, the playwright also said, "I don't want no Catholic mass. I want a black funeral at St. Paul's Cathedral." But when the bishop of the church rejected that request, Udin was forced to move the service to the Soldier's and Sailor's Memorial Hall, located on the campus of the University of Pittsburgh. The rest of the playwright's wishes went as requested. Dwight Andrews, a professor of music at Emory who had composed the score for several Wilson plays on Broadway, delivered the eulogy. Many prominent theater professionals and academics attended. Just as Udin appeared satisfied that his friend's sendoff went as planned, something unexpected occurred that deserves repeating verbatim as Udin recalls it:

As we are wrapping up, I hear a horn backstage. And I figured, "Oh damn. Somebody who is using this space next is rehearsing while we are wrapping up." So I sent somebody backstage to tell them to hold up until we were done. But the music kept playing. And then I recognized the tune. Somebody was on a trumpet playing "Danny Boy." I had no idea what was going on, and I was supposed to be in charge. And the music became louder. And out from backstage comes the trumpet player Wynton Marsalis. Constanza had snuck him back there. He comes out blowing "Danny Boy." There was not a dry eye in the room. And then at the end of "Danny Boy" he reaches into his back pocket and pulls out a white handkerchief and starts waving it and starts playing "When the Saints Go Marching In." And he led everybody off stage, down through the audience, and to the casket. And the pall bearers took the casket up the aisle and out of the auditorium. Marsalis led everybody from behind the casket, and everybody who had a handkerchief was waving their handkerchiefs, laughing and crying, as we left Soldier's and Sailor's Memorial Hall.

This climactic moment was followed by a funeral procession through the Hill District, as locals said goodbye to their most famous resident and favorite son. As the procession wound through streets Udin and Wilson had walked together as young men, people held up signs that read "WE LOVE YOU AUGUST" and "WE MISS YOU AUGUST," coupled with others that bore the names of Wilson's plays. The funeral party finally went out to Greenwood 
Cemetery, where generations of black Pittsburghers are buried, including Wilson's mother, and laid the playwright to rest.

Yet Wilson's funeral was not the last time Udin bonded with his friend. In 2010, Udin found himself reprising the role of Becker in Jitney, the play he reluctantly helped Wilson inaugurate in 1982. This time the performance was more personal. When he first played Becker, Udin jokes that the role required significant makeup and practice "learning how to walk like an old man." In 2010, Udin was actually older than how Becker is written, and "I didn't need no makeup in my hair, and I didn't need no practice in how to walk like an old man." Beneath these humorous recollections, however, lay something far more serious. In a twist of fate that one might think could happen only in a piece of fiction that a writer such as Wilson might pen, Udin's son Patrice Howze, "my baby," was found dead on Centre Avenue, less than twenty-four hours after Wilson's funeral. He was murdered. Udin says, "He had gotten into that drug life. The thug life. And the ultimate end that comes to so many visited him." Udin found himself again connecting with the father-son conflict at the heart of Jitney, remembering the struggle between him and Patrice during "most of his teenage years and young adult years, as I was trying to pull him out from the streets and from negativity, and he was determined to do what he wanted to do. And the conflict between Patrice and I was so similar to the conflict between Becker and Booster that the play took on a much more personal meaning and deeper meaning." When asked how all this affected his performance, Udin says, "I cried real tears on the stage. And the line at the end of act one, when Becker says to Booster 'You just another nigger on the street,' was like a dagger to the heart."

\section{The Hill District 2018}

On April 28, 2018, a cold, overcast day, the third annual August Wilson Block Party commenced along Bedford Avenue, the same street Wilson and Udin roamed as children. For several years, various media reports have touted what appears to be a sustained revitalization of the Hill District. Udin expresses a reserved optimism. While a grocery store finally opened on Centre Avenue in 2013, Udin points out it is not a major chain, expressing skepticism about its possibilities for success. The long-time activist was prescient: A few months after this interview, in March of 2019, the Shop'n Save closed, rendering the Hill District a food desert once again. When asked about reports celebrating the opening of a full-service pharmacy in the Hill, Udin points out that these stories are misleading, as the pharmacy is operated by Duquesne University, with limited, inconvenient hours for many. And while housing has improved in the Middle Hill District, that change remains incremental at best. When asked if reports of the positive changes in the Hill District distort the reality that still faces a host of problems that accompany most low socioeconomic communities comprised of mostly African Americans, Udin agreed.

Yet all that seemed far in the background as hundreds of residents celebrated what would have been August Wilson's seventy third birthday. Udin says the event was "off the chain." The event also featured the groundbreaking of the newly named August Wilson House at 1727 Bedford Avenue, where Wilson grew up with his six siblings. The building, already listed on the National Register of Historic Places, will serve as an artist's residence and cultural center once fully refurbished. Also at the Block Party were members of the August Wilson Society, a group of academics and theater professionals dedicated to preserving the legacy of the playwright.

The highlight of the festivities was the Pittsburgh Playwrights Theatre company's production of King Hedley II in the very backyard of the building Wilson was raised some seventy years prior. Sala Udin, ever the reluctant performer, was to play Stool Pigeon, one of Wilson's famed "Spectacle Characters," individuals who appear mentally unbalanced yet also possess seer-like wisdom. King Hedley II, set in 1985, is often noted as Wilson's darkest play, 
one with an apocalyptic vision of the state of the African American community at this time in history. Udin notes that this is the hardest of all the Wilson characters he has tackled because of the play's relentlessly bleak tone. "It was bad," Udin says with a chuckle, "but it wasn't that bad." Unfortunately, bad weather canceled the opening weekend of the show and several performances in the coming weeks, but reviews of the productions that went on were positive. Udin himself was pleased with the production. It seemed another example of what he had witnessed his whole life. That while forces may seek to drag down what those who live and work in the Hill District try to accomplish, the final knockout blow still has not come. And it appears that blow cannot be delivered. For while August Wilson may belong to the world, he still belongs to the Hill District, and as Sala Udin has witnessed his entire life, both the plays and the neighborhood in which they are set possess an endurance that cannot be outrun.

\section{Author Bio}

Dr. Christopher Bell is Associate Professor of English at the University of North Georgia where he teaches courses in American Literature, African American Literature, and World Drama.

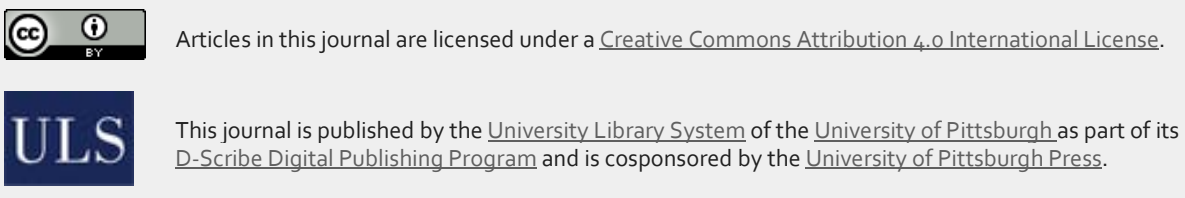

